\title{
Evaluation of the prevalence of sexually transmitted bacterial pathogens in Northern Cyprus by nucleic acid amplification tests, and investigation of the relationship between these pathogens and cervicitis
} Kuzey Kıbris'ta cinsel yolla bulaşan bakteriyel patojenlerin prevelansının nükleik asit amplifikasyon testleri ile incelenmesi ve bu patojenlerin servisitle olan ilişkilerinin araştırılması

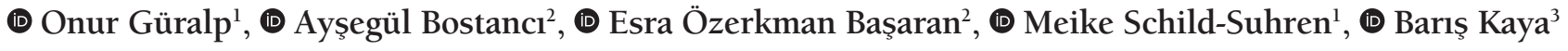 \\ ${ }^{1}$ Carl von Ossietzky Oldenburg University Faculty of Medicine, Obstetrics and Gynecology, Klinikum AöR, Oldenburg, Germany \\ 2 Near East University Faculty of Medicine, Department of Molecular Biology and Genetics, Lefkosa-TRNC, Turkey \\ ${ }^{3}$ Near East University Faculty of Medicine, Department of Obstetrics and Gynecology, Nicosia, Northern Cyprus
}

\begin{abstract}
Objective: To evaluate the prevalence of pathogens, Chlamydia trachomatis, Neisseria gonorrhea and Trichomonas vaginalis, Mycoplasma hominis, Mycoplasma genitalium, Ureaplasma urealyticum, and Ureaplasma parvum in women via multiplex-polymerase chain reaction (PCR)-deoxyribonucleic acid (DNA).

Materials and Methods: Cervical swabs of 273 women in reproductive age who underwent gynecologic examination in our outpatient clinic were evaluated using the multiplex-PCR-DNA method. The presence of cervicitis, contraceptive methods, marital status, and the number of partners were evaluated.

Results: One hundred six (39\%) of the 273 women had at least one bacterium, 25 women (9.8\%) had two bacteria, and three women (1\%) had three bacteria. U. urealyticum was the most frequently encountered bacterium (13.9\%), followed by M. hominis (12.8\%), U. parvum (12.4\%), C. trachomatis (5.4\%), M. genitalium (2.9\%), N. gonorrhea (2.5\%), and T. vaginalis (0.3\%). Bacterial infection was detected more frequently in women aged $<25$ years, single, who had multiple partners, and clinically diagnosed with cervicitis. The cervicitis rate was 39\% in our study. M. genitalium was significantly more frequent in women with cervicitis than in women without cervicitis (5.6 vs. 1.2\%, p=0.005). C. trachomatis and N. gonorrhea, which are often associated with cervicitis, were comparable in women with and without cervicitis.

Conclusion: Women with clinically diagnosed cervicitis or even with a normal-appearing cervix should be tested using multiplex-real-time PCR-nucleic-acidamplification tests on suspicion of such an infection. M. genitalium is an emerging bacterial agent for cervicitis along with C. trachomatis and N. gonorrhea.
\end{abstract}

Keywords: Chlamydia, neisseria, trichomonas, mycoplasma, ureaplasma

$\ddot{O} z$

Amaç: Kadınlarda multipleks-polimeraz zincir reaksiyonu (PCR)-deoksiribonükleik asit (DNA) ile Chlamydia trachomatis, Neisseria gonorrhea ve Trichomonas vaginalis, Mycoplasma hominis, Mycoplasma genitalium, Ureaplasma urealyticum ve Ureaplasma parvum patojenlerinin görülme sıklı̆̆ın değerlendirmek ve klinik olarak servisit tanısı koyulan kadınlardaki bu bakterilerin rolünü incelemek.

Gereç ve Yöntemler: Polikliniğimizde jinekolojik muayeneye gelen üreme çă̆ındaki 273 kadından alınan serviks sürüntüsü multipleks-PCR-DNA yöntemiyle incelendi. Servisit varlığı, kontraseptif yöntemler, evlilik durumu ve partner sayısı değerlendirildi.

Bulgular: İki yüz yetmiş üç kadından 106'sında (\%39) en az bir bakteri tespit edilirken, 25 kadında $(\% 9,8)$ iki bakteri, 3 kadında ise (\%1) üç bakteri tespit edildi. U. urealyticum $(\% 13,9)$ en slk tespit edilen bakteri olup, sikllk sirasına göre M. hominis (\%12,8), U. parvum (\%12,4), C. trachomatis (\%5,4), M. genitalium (\%2,9), N. gonorrhea $(\% 2,5)$ ve T. vaginalis $(\% 0,3)$ oranında saptandı. Bakteriyel infeksiyon 25 yaşın altında, bekar, birden fazla partneri olan ve klinik olarak servisit tanısı

PRECIS: To identify the possible risk factors for postpartum urinary retention.

Address for Correspondence/Yazışma Adresi: Onur Güralp, MD,

Carl von Ossietzky Oldenburg University Faculty of Medicine, Obstetrics and Gynecology, Klinikum AöR, Oldenburg, Germany

Phone: +49 4414032288 E-mail: dronur@hotmail.com ORCID ID: orcid.org/0000-0002-3517-3046

Received/Gelis Tarihi: 24.05.2019 Accepted/Kabul Tarihi: 12.10.2019

${ }^{\circ}$ Copyright 2019 by Turkish Society of Obstetrics and Gynecology

Turkish Journal of Obstetrics and Gynecology published by Galenos Publishing House 
koyulan kadınlarda daha sık gözlendi. Çalışmamızda servisit oranı \%39 olarak saptandı. M. genitalium servisit görülen kadınlarda servisit görülmeyen kadınlara kıyasla anlamlı olarak daha sık saptandı (\%5,6’ya karşılık \%1,2, p=0,005). Sıllıkla servisitle ilişkilendirilen C. trachomatis ve N. gonorrhea’nın görülme oranları benzer olarak saptandi.

Sonuç: Klinik olarak servisit tanısı koyulan kadınlarda veya enfeksiyon şüphesi varsa normal görünümdeki serviks varlğ̆ında bile multipleks-PCR-nükleik asit amplifikasyon testleri kullanılmalıdır. M. genitalium, C. trachomatis ve N. gonorrhea'nın ardından bakteriyel servisit etkeni olarak öne çımaktadır.

Anahtar Kelimeler: Klamidya, neisseria, trikomonas, mikoplazma, üroplazma

\section{Introduction}

Every year, more than 1 million people are infected with sexually transmitted diseases (STDs) ${ }^{(1)}$. Chlamydia trachomatis, Neisseria gonorrhea and Trichomonas vaginalis are the very wellknown sexually transmissible pathogens, whereas Mycoplasma genitalium has recently gained importance in the pathogenesis of cervicitis ${ }^{(2)}$. These bacteria are either asymptomatic or present themselves with mild symptoms, which may easily be overlooked $^{(1)}$. These bacterial STDs may lead to tubal infertility and extrauterine pregnancy as well as chronic pelvic pain, which is associated with a severe socioeconomic burden ${ }^{(1)}$. Besides Mycoplasma hominis and Ureaplasma urealyticum, Ureaplasma parvum may be commensally colonized in the cervix. However, some authors suggest that such colonization may be associated with poor obstetric outcome, postpartum sepsis, and neonatal infections ${ }^{(3)}$. The serologic diagnosis or traditional culture media may not be sufficient for diagnosis ${ }^{(2,4)}$. In some cases, the presence of multiple agents makes it even more difficult to diagnose the actual agents ${ }^{(4)}$. For that reason, due to their high sensitivity and specificity for the diagnosis of STDs, as well their ability to diagnose more than one pathogen at once, multiplex real-time polymerase chain reaction (PCR) nucleic acid amplification tests (NAAT) have gained popularity over conventional microbiologic culture methods ${ }^{(4-6)}$. In this study, we aimed to evaluate the prevalence of pathogens including $C$. trachomatis, N. gonorrhea, T. vaginalis, M. hominis, M. genitalium, $U$. urealyticum and $U$. parvum in women via multiplex PCR DNA tests, and to assess the role of these bacteria in women with clinically diagnosed cervicitis who were admitted to our outpatient clinic in Near East University for gynecologic examinations.

\section{Material and Methods}

In this study, the cervical swabs of 273 women in reproductive age who were admitted for gynecologic examinations with symptoms of vaginal discharge or who asked for a screening of sexually transmitted infections without any symptoms to the outpatient clinic of Near East University, Department of Obstetrics and Gynecology, between 2014 and 2016, were examined using the multiplex PCR DNA method. The results were retrospectively evaluated. The study was approved by the Ethics Committee of Near East University on March 31 $31^{\text {st }}$, 2016 (number: of 2016/36-266). Informed and signed consent was obtained from all participants. Inclusion criteria were apparently healthy, sexually active women aged $>18$ years without pelvic pain or fewer, who were not pregnant, and had not received antibiotic recently for a gynecologic infection. Women with pelvic inflammatory disease (PID) were excluded from the study. All women had a gynecologic examination, and the presence of cervicitis, contraceptive methods, marital status, and the number of partners were documented.

Cervicitis was described as the presence of purulent or mucopurulent discharge and/or hyperemic, edematous and friable (bleeding even with a light touch of a cervical swab) cervix ${ }^{(7,8)}$. The cervical swabs from participants were taken by gynecologists using a single-use speculum with the manufacturer's kits and were sent to the genetic laboratory.

\section{Nucleic Acid Isolation Procedure}

Nucleic acid isolation was performed in accordance with the manufacturer's instructions (GeneAll RibospinTM vRD). Swab samples were obtained from the cervix and then transferred to the Medical Genetics Laboratory of Near East University Hospital. The following steps were performed: Centrifugation at $5000 \mathrm{rpm}$ for 15 minutes, addition of buffer (VL, $500 \mu \mathrm{L})$, incubation for $10 \mathrm{~min}$ at $25^{\circ} \mathrm{C}$, addition of buffer $(700 \mu \mathrm{L}$ RB1), and vortexing. Preparation of the spin column. Removal of residual buffer by centrifugation of the mixture at $12,000 \mathrm{~g}$. Addition of nuclease-free $\mathrm{H}_{2} \mathrm{O}$. Re-centrifugation at over 10,000 $\mathrm{g}$ for 60 seconds. The purified nucleic acid was kept at $4{ }^{\circ} \mathrm{C}$ for direct analysis and kept at $-70^{\circ} \mathrm{C}$ for subsequent analysis.

\section{Polymerase Chain Reaction}

PCR was conducted for detecting the STD panel. The fast track diagnostic urethritis plus real-time PCR kit was used for analysis, which examines C. trachomatis, N. gonorrhea, T. vaginalis, M. hominis, M. genitalium, $U$. urealyticum, and $U$. parvum. The DNA amplification reactions were performed using Qiagen Rotor-gene Q. After the DNA amplification, the results were interpreted according to the given fluorescence trace of the positive samples. The results were examined using the data supplied by the manufacturer.

\section{Statistical Analysis}

Continuous parametric variables are given as mean and standard deviation. Categorical variables are expressed as number or percentage. T-test or analysis of variance were used for the comparison of parametric variables. Categorical variables were compared using the chi-square $\left(\chi^{2}\right)$ test. Statistical calculations were performed using Statistical Package for Social Sciences (SPSS 15.0, Chicago, IL, USA). P $<0.05$ was accepted as significant. 


\section{Results}

A total of 273 women were included in this study. The demographic and clinical features of the patients are given in Table 1. The mean age of the women was $31.03 \pm 9.20$ years. The study group consisted mainly of married women (70\%), with a single partner (85\%); $39.5 \%$ of the women had cervicitis. One hundred six (39\%) of the 273 women had at least one bacterium, 25 women (9.8\%) had two bacteria, and 3 women (1\%) had three bacteria. Among the 273 women, U. urealyticum was the most frequently encountered bacterium in the cervix (13.9\%), followed by M. hominis (12.8\%), U. parvum (12.4\%), C. trachomatis (5.4\%), M. genitalium (2.9\%), N. gonorrhea (2.5\%), and $T$. vaginalis $(0.3 \%)$. The infection rates according to the age, marital status, number of partners, the presence

Table 1. The demographic and clinical features of the patients

\begin{tabular}{|l|l|l|}
\hline Number & \\
of & percent \\
& women & $(\%)$
\end{tabular}

\section{Age groups}

\begin{tabular}{|c|c|c|}
\hline$<25$ years & 83 & 30.40 \\
\hline $26-30$ years & 78 & 28.57 \\
\hline $31-35$ years & 48 & 17.58 \\
\hline$>36$ years & 64 & 23.44 \\
\hline \multicolumn{3}{|l|}{ Marital status } \\
\hline Single & 81 & 29.67 \\
\hline Married & 192 & 70.33 \\
\hline \multicolumn{3}{|l|}{ Number of partners } \\
\hline One & 233 & 85.35 \\
\hline Multiple & 40 & 14.65 \\
\hline \multicolumn{3}{|l|}{ Deliveries } \\
\hline No & 122 & 44.69 \\
\hline Yes & 151 & 55.31 \\
\hline \multicolumn{3}{|l|}{ Vaginal discharge } \\
\hline Absent & 231 & 84.62 \\
\hline Present & 42 & 15.38 \\
\hline \multicolumn{3}{|l|}{ Cervicitis } \\
\hline absent & 165 & 60.44 \\
\hline present & 108 & 39.56 \\
\hline \multicolumn{3}{|l|}{ Contraceptive method } \\
\hline Condom & 17 & 6.23 \\
\hline Withdrawal (coitus interruptus) & 160 & 58.61 \\
\hline Oral contraceptives & 63 & 23.08 \\
\hline Intrauterine device & 33 & 12.09 \\
\hline
\end{tabular}

of cervicitis, and type of contraceptive method are presented in Table 2. Bacterial infection was detected more frequently in women aged $<25$ years, those who were single, who had multiple partners, and clinically diagnosed with cervicitis. Bacterial infection was detected less frequently in women who used a condom as a contraceptive method. M. hominis was the most commonly seen bacterium in women aged under 25 years. M. hominis and $U$. urealyticum were significantly more common in women with multiple partners. The cervicitis rate

Table 2. The infection rates according to the age, marital status, number of partners, vaginal mucopurulent discharge, presence of cervicitis and type of contraceptive method

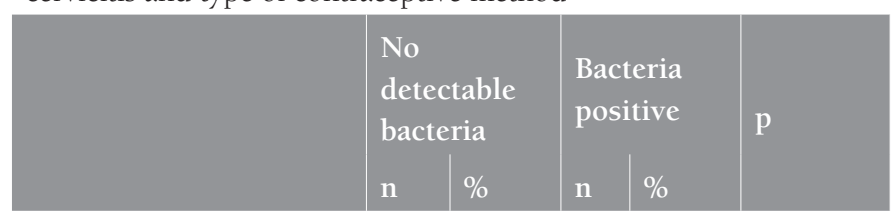

Age groups

\begin{tabular}{llllll|}
$<25$ years & 42 & 50.60 & 41 & 49.40 & 0.09 \\
$26-30$ years & 50 & 64.10 & 28 & 35.90 & \\
\hline $31-35$ years & 30 & 62.50 & 18 & 37.50 & \\
$>36$ years & 45 & 70.31 & 19 & 29.69 & \\
\hline
\end{tabular}

Marital status

$\begin{array}{llllll}\text { Single } & 36 & 44.44 & 45 & 55.56 & <0.001^{* *} \\ \text { Married } & 131 & 68.23 & 61 & 31.77 & \end{array}$

Number of partners

\begin{tabular}{llllll} 
One & 155 & 66.52 & 78 & 33.48 & $<0.001^{* *}$ \\
Multiple & 12 & 30.00 & 28 & 70.00 & \\
$\begin{array}{l}\text { Parity } \\
\text { No }\end{array}$ & 65 & 53.28 & 57 & 46.72 & $0.02^{*}$ \\
Yes & 102 & 67.55 & 49 & 32.45 & \\
\hline
\end{tabular}

\section{Complaint}

$\begin{array}{lllll}\text { Asymptomatic } & 147 & 63.64 & 84 & 36.36\end{array}$

Vaginal mucopurulent $\quad 20-47.62-22 \quad 52.38 \quad 0.05^{*}$ discharge

\section{Cervicitis}

$\begin{array}{llllll}\text { Absent } & 110 & 66.67 & 55 & 33.33 & 0.02 * \\ \text { Present } & 57 & 52.78 & 51 & 47.22 & \end{array}$

\section{Contraceptive method}

\begin{tabular}{|c|c|c|c|c|c|}
\hline Condom & 16 & 94.12 & 1 & 5.88 & $0.03 *$ \\
\hline $\begin{array}{l}\text { Withdrawal (coitus } \\
\text { interruptus) }\end{array}$ & 93 & 58.13 & 67 & 41.88 & \\
\hline Oral contraceptives & 36 & 57.14 & 27 & 42.86 & \\
\hline Intrauterine device & 22 & 66.67 & 11 & 33.33 & \\
\hline
\end{tabular}

Chi-square test, $p<0.05$ was accepted as statistically significant 
was 39\% among the 273 women in our study. Among women with cervicitis, M. genitalium was significantly more frequent in women with cervicitis than in those without cervicitis (5.6\% vs. $1.2 \% \mathrm{p}<0.005)$. C. trachomatis and N. gonorrhea, which are often associated with cervicitis, were comparable in women with and without cervicitis. In 55 (33\%) of 165 women with no clinical cervicitis, at least one bacterium was detected, and 15 (9\%) women had at least one of the bacteria known to be associated with cervicitis, such as C. trachomatis, N. gonorrhea, M. genitalium or T. vaginalis. By contrast, among 108 women with clinical cervicitis, the rate of the bacteria known to be associated with cervicitis was $14.9 \%$ (9\% vs. $14.9 \%$; $\mathrm{p}=0.133$ ). The rates of simultaneous infections with multiple bacteria were comparable between women with and without cervicitis (9.3\% vs. $11.5 \%, \mathrm{p}=0.565)$.

\section{Discussion}

In our study, 39\% of women had at least one bacterium. Among the 273 women, U. urealyticum was the most frequently encountered bacterium in the cervix (13.9\%), followed by $M$. hominis (12.8\%), U. parvum (12.4\%), which showed a balanced distribution. The detection rate of bacteria was reported to vary between 30.7 and $49 \%$ in previous screened populations ${ }^{(4,5)}$. Kim et al. ${ }^{(5)}$ screened 799 Korean women and detected at least one bacterium in $49 \%$ of women. Contrary to our study, U. parvum was the most frequently (32.5\%) found bacterium, followed by U. urealyticum (3.5\%) and M. hominis (1\%). Lee et al. ${ }^{(4)}$ screened 304 women and detected bacteria in $36.5 \%$, most frequently $U$. urealyticum (14.5\%), followed by M. hominis (13.8\%). In south Italy, Del Prete et al. ${ }^{(9)}$ screened 1272 women and detected at least one bacterium in $30.7 \%$ of women. The most commonly detected bacterium was by far U. parvum (25.9\%). In our study, we detected the bacterial colonization of $U$. parvum with a rate of $12.4 \%$. Yamazaki et al. ${ }^{(10)}$ reported high detection rates of U. parvum as $41.7 \%$. Yamazaki et al. ${ }^{(10)}$ suggested that the high prevalence of the latter two bacteria might be attributed to the region, culture, and tendency to nightlife. Camporiondo et al. ${ }^{(6)}$ performed a screening study in 309 Italian women and detected no C. trachomatis, M. genitalium or N. gonorrhea, but U. parvum (28.8\%), M. hominis (3.9\%) and U. urealyticum (4.5\%). McIver et al. ${ }^{(11)}$ evaluated 175 sexually active Australian women and detected U. parvum (53\%), M. hominis (7.4\%), and $U$. urealyticum $(3.4 \%)$ in descending order. Simultaneous infection rates with $U$. parvum $+M$. hominis, $U$. urealyticum $+M$. hominis and $U$. urealyticum $+U$. parvum were $7.4 \%, 1.1 \%$, and $2.9 \%$, respectively. In our study U. urealyticum, M. hominis, and $U$. parvum were among the most commonly detected bacteria in the cervix. They are accepted as genital commensalistic organisms and found in healthy women ${ }^{(10)}$. Routine screening and treatment of the latter three bacteria are controversial ${ }^{(10)}$. Some authors suggest that colonization with $U$. urealyticum and $U$. parvum in high density is associated with non-specific cervicitis $^{(12)}$, whereas others suggest that there is not enough evidence to suggest that these bacteria cause cervicitis or PID ${ }^{(13)}$. However, several studies in pregnant women showed that the presence of these bacteria in amniotic-fluid or membranes might be associated with preterm labor, preterm premature rupture of membranes (PPROM), and neonatal infections ${ }^{(14-24)}$. Abele-Horn et al. ${ }^{(21)}$ showed that $U$. urealyticum was associated with preterm labor. Kataoka et al. ${ }^{(22)}$ evaluated 877 pregnant women under 11 gestational weeks (GW) and detected the prevalence rates of $U$. urealyticum, M. hominis, and $U$. parvum as $52.0 \%, 11.2 \%$, and $8.7 \%$, respectively. Despite the higher prevalence of U. urealyticum in the latter study, U. parvum had a stronger association with late abortion and preterm labor compared with $U$. urealyticum ${ }^{(22)}$. One hundred eightyfour pregnancies complicated with preterm labor and PPROM were evaluated in a prospective study and coinfection with $M$. hominis, and U. urealyticum was shown to be associated with poorer pregnancy outcomes compared with infection with $U$. urealyticum alone ${ }^{(23)}$. In another study, vaginal $U$. urealyticum and U. parvum colonization were also shown to be associated with chorioamnionitis in pregnancies under $28 \mathrm{GW}$ complicated with PPROM ${ }^{(24)}$. Rumyantseva et al. ${ }^{(25)}$ recently evaluated 1773 women and observed that the isolation rates of $U$. parvum and M. hominis in women with bacterial vaginosis were significantly higher in women with altered vaginal microflora compared with women with normal vaginal flora. Chlamydia is known to be the most common $\mathrm{STD}^{(26,27)}$. It is one of the major organisms causing cervicitis and PID, even if it is asymptomatic. In our study, the prevalence of C. trachomatis was 5.4\%, which was more frequent than other sexually transmissible bacteria such as M. genitalium (2.9\%), N. gonorrhea (2.5\%) and T. vaginalis $(0.3 \%)$. Chlamydia prevalence, along with the prevalence of other STDs, may vary according to the age, race, region, and socioeconomic status ${ }^{(26,28)}$. The prevalence of chlamydia was reported as $0.6 \%$ in Australia ${ }^{(11)}, 2.6 \%$ in the Netherlands ${ }^{(29)}$, $2.3 \%$ in $\mathrm{China}^{(30)}$, and as high as $14.2 \%$ in South Africa ${ }^{(31)}$. The prevalence of chlamydia in the United States of America (USA) was reported to be $4.2 \%$ in the general population, but as high as $10 \%$ in Mexicans living in the USA (26). In a systematic review and meta-analysis, the prevalence of chlamydia in Europe and developed countries such as Canada, Australia, and New Zealand was reported as $3.0-5.3 \%{ }^{(28)}$, which is also concordant with the values in our study. In the present study, the prevalence of gonorrhea was $2.5 \%$. Gonorrhea is the second most common sexually transmitted bacterial infection following chlamydia ${ }^{(26)}$. According to the World Health Organization report in 2012, the global gonorrhea prevalence varies between $0.3 \%$ and $1.7 \%{ }^{(1)}$. In our study, the prevalence of gonorrhea was significantly over the global average. Nevertheless, the prevalence of STD may vary according to the country or even to the region in the same country. Kim et al. ${ }^{(5)}$ evaluated 799 Korean women and detected no gonorrhea, whereas Lee et al. ${ }^{(4)}$ evaluated 304 Korean women and detected gonorrhea in $3.3 \%$ of the screened population, which was even higher than 
in our study group. Gaydos et al. ${ }^{(32)}$ evaluated a group of 324 women comprising mainly young African-American women in Baltimore, USA, and detected the rate of gonorrhea as $4.6 \%$. The high rates of gonorrhea in our study may be attributed to the presence of nightclubs in our region. In our study, the rate of $M$. genitalium infection was $2.9 \%$. The global M. genitalium infection rate is reported as $1-6.2 \%{ }^{(33)}$. Nevertheless, prevalence rates as high as $19.2 \%$ have also been reported ${ }^{(32)}$. Nowadays, since the widespread use of NAATs in recent years, M. genitalium counts as one of the most important bacteria, following $N$. gonorrhea and C. trachomatis, causing cervicitis ${ }^{(34)}$. The prevalence of $T$. vaginalis was $0.3 \%$ in our study. T. vaginalis is the most common non-viral sexually transmissible infection in the USA and may cause urethritis in men and women, and vaginitis and cervicitis in women ${ }^{(35)}$. It is hard to determine the true prevalence of $T$. vaginalis because the feedback is not so efficient as with other STD pathogens. According to the Centers for Disease Control and Prevention, the prevalence of $T$. vaginalis in non-Hispanic women in the USA is $1.8 \%{ }^{(2)}$. Moreover, in hitherto literature, prevalences of $T$. vaginalis as low as $0.1 \%$ have been reported ${ }^{(5)}$.

\section{Cervicitis}

In our study, the cervicitis rate was 39\% among 273 women, which is similar to the $41 \%$ among 324 women reported by Gaydos et al. ${ }^{(32)}$. Gaydos et al. ${ }^{(32)}$ detected that $C$. trachomatis and M. genitalium were associated with cervicitis; however, only M. genitalium had a significant association with cervicitis in multiple regression analysis. In our study, the M. genitalium infection rate was significantly elevated in women with clinical cervicitis compared with women without cervicitis, which supports recent data about the importance of M. genitalium as an emerging pathogen of cervicitis. The clinical diagnosis of cervicitis is not always suggestive for a sign of bacterial infection. It has been shown that no infectious pathogen is detectable in the majority of women with clinical cervicitis ${ }^{(36)}$. Nevertheless, N. gonorrhea and C. trachomatis have long since been reported to be the most frequent bacteria causing cervicitis, if a pathogen is detectable ${ }^{(37,38)}$. Along with $N$. gonorrhea and C. trachomatis, M. genitalium, T. vaginalis, and Herpes simplex virus, as well as
Gardnerella vaginalis, may cause cervicitis ${ }^{(34)}$. In our study, there was no detectable bacterial pathogen with NAAT PCR DNA in 57 of 108 women (52\%) with clinical cervicitis. At this point, it should be mentioned that etiologic factors of non-infectious cervicitis include chemical or physical trauma, vaginal douche, idiopathic inflammation of the cervix, and Behçet' disease ${ }^{(2)}$. In our study, in 55 (33\%) of 165 women with no clinical cervicitis at least bacterium was detected, and fifteen (9\%) women had at least one of the bacteria known to be associated with cervicitis, such as C. trachomatis, $N$. gonorrhea, M. genitalium or T. vaginalis. By contrast, among 108 women with clinical cervicitis, the rate of the bacteria known to be associated with cervicitis was $14.9 \%$. The coinfection rates in women with and without cervicitis were comparable in our study, concordant with the findings of Gaydos et al. ${ }^{(32)}$. Studies about the detection rates of infectious agents causing vaginitis and cervicitis are summarized in Table $3^{(4-6,9,11,32,39)}$. In our study, it has been shown that multiplex realtime PCR-NAAT is beneficial for the demonstration of cervical bacterial colonization with commensal pathogens including $U$. urealyticum, M. hominis, and U. parvum or with pathogens that can cause cervicitis such as $C$. trachomatis, $N$. gonorrhea, and M. genitalium. The major limitation of these techniques is their high $\operatorname{costs}^{(40)}$.

\section{Conclusion}

In our study the prevalence of sexually transmitted bacteria in the Northern Cyprus region was consistent with the literature. M. genitalium was detected to be more frequent in women with cervicitis than in women without cervicitis $(5.6 \%$ vs. $1.2 \%$ $\mathrm{p}<0.005)$. C. trachomatis and $N$. gonorrhea, which are often associated with cervicitis, were comparable in women with and without cervicitis.

According to our study results, women either diagnosed with cervicitis or with a normal-appearing cervix should be tested with multiplex-real-time PCR-NAATs on suspicion of such an infection. There was no significant difference regarding simultaneous infection with multiple bacteria between women with and without cervicitis.

Table 3. Studies about the detection rates of infectious agents causing vaginitis and cervicitis

\begin{tabular}{|c|c|c|c|c|c|c|c|c|}
\hline & $\begin{array}{l}\text { Present } \\
\text { study } \% \\
(n=273)\end{array}$ & $\begin{array}{l}\text { Lee et } \\
\text { al. }{ }^{(4)} \\
(n=304)\end{array}$ & $\begin{array}{l}\text { Kim et al. }{ }^{(5)} \\
(n=799)\end{array}$ & $\begin{array}{l}\text { McIver et } \\
\text { al. }^{(11)} \\
(\mathrm{n}=175)\end{array}$ & $\begin{array}{l}\text { Camporiondo et } \\
\text { al. }{ }^{(6)} \\
(n=309)\end{array}$ & $\begin{array}{l}\text { Del Prete } \\
\text { et al. }{ }^{(9)} \\
(n=1272)\end{array}$ & $\begin{array}{l}\text { Choe et } \\
\text { al. }{ }^{(39)} \\
(n=201)\end{array}$ & $\begin{array}{l}\text { Gaydose } \\
\text { et al. }{ }^{(32)} \\
(n=324)\end{array}$ \\
\hline U. urealyticum & 13.9 & 14.1 & 7.6 & 6.1 & 4.5 & 5.1 & 40.3 & - \\
\hline M. hominis & 12.8 & 13.8 & 9.9 & 13.7 & 3.9 & 5.9 & 14.9 & - \\
\hline U. parvum & 12.4 & - & 42 & 57 & 28.8 & 24.9 & 52.7 & - \\
\hline C. trachomatis & 5.4 & 3.0 & 1.1 & 0.6 & - & 1.8 & 4.0 & 11.1 \\
\hline M. genitalium & 2.9 & 0.3 & 1.0 & 1.3 & - & 0.3 & 4.0 & 19.2 \\
\hline N. gonorrhoeae & 2.5 & 3.3 & 0.0 & - & - & 0.1 & 1.5 & 4.6 \\
\hline T. vaginalis & 0.3 & 2.0 & 0.1 & 4.0 & 1.3 & 1.4 & 1.0 & 15.3 \\
\hline
\end{tabular}




\section{Ethics}

Ethics Committee Approval: The study was approved by the Ethics Committee of the Near East University in 31.03.2016 with the number of 2016/36-266.

Informed Consent: Informed and signed consent was obtained from all participants.

Peer-review: Internally peer-reviewed.

\section{Authorship Contributions}

Concept: O.G., Data Collection or Processing: O.G., B.K., Analysis or Interpretation: O.G., A.B., E.Ö.B., Literature Search: O.G., M.S.S., Writing: O.G.

Conflict of Interest: No conflict of interest was declared by the authors.

Financial Disclosure: The authors declared that this study received no financial support.

\section{References}

1. http://www.who.int/news-room/fact-sheets/detail/sexuallytransmitted-infections-(STIs) accessed at 27.11.2018.

2. Centers for Disease Control and Prevention. Diseases characterized by urethritis and cervicitis. https://www.cdc.gov/std/tg2015/ urethritis-and-cervicitis.htm. Accessed October 26, 2017.

3. Rodrigues MM, Fernandes PÁ, Haddad JP, Paiva MC, Souza MC, Andrade TC, et al. Frequency of Chlamydia trachomatis, Neisseria gonorrhoeae, Mycoplasma genitalium, Mycoplasma hominis and Ureaplasma species in cervical samples. J Obstet Gynaecol 2011;31:237-41.

4. Lee SJ, Park DC, Lee DS, Choe HS, Cho YH. Evaluation of Seeplex® STD6 ACE Detection kit for the diagnosis of six bacterial sexually transmitted infections. J Infect Chemother 2012;18:494-500.

5. Kim Y, Kim J, Lee KA. Prevalence of sexually transmitted infections among healthy Korean women: implications of multiplex PCR pathogen detection on antibiotic therapy. J Infect Chemother 2014;20:74-6.

6. Camporiondo MP, Farchi F, Ciccozzi M, Denaro A, Gallone D, Maracchioni F, et al. Detection of HPV and co-infecting pathogens in healthy Italian women byreal-time multiplexe PCR. Infez Med 2016;24:12-7.

7. Workowski KA, Bolan GA, Centers for Disease Control and Prevention. Sexually transmitted diseases treatment guidelines, 2015. MMWR Recomm Rep 2015;64:1.

8. Marrazzo JM, Martin DH. Management of women with cervicitis. Clin Infect Dis 2007;S102.

9. Del Prete R, Ronga L, Lestingi M, Addati G, Angelotti UF, Di Carlo $D$, et al. Simultaneous detection and identification of STI pathogens by multiplex Real-Time PCR in genital tract specimens in a selected area of Apulia, a region of Southern Italy. Infection 2017;45:46977.

10. Yamazaki T, Matsumoto M, Matsuo J, Abe K, Minami K, Yamaguchi $\mathrm{H}$. Frequency of Chlamydia trachomatis in Ureaplasma- positive healthy women attending their first prenatal visit in a community hospital in Sapporo, Japan. BMC Infect Dis 2012;12:82.

11. McIver CJ, Rismanto N, Smith C, Naing ZW, Rayner B, Lusk MJ, et al. Multiplex PCR testing detection of higher-than-expected rates of cervical mycoplasma, ureaplasma, and trichomonas and viral agent infections in sexually active australian women. J Clin Microbiol 2009:47:1358-63.
12. Liu L, Cao G, Zhao Z, Zhao F, Huang Y. High bacterial loads of Ureaplasma may be associated with non-specific cervicitis. Scand J Infect Dis 2014:46:637-41.

13. Horner P, Donders G, Cusini M, Gomberg M, Jensen JS, Unemo M. Should we be testing for urogenital Mycoplasma hominis, Ureaplasma parvum and Ureaplasma urealyticum in men and women? - a position statement from the European STI Guidelines Editorial Board. J Eur Acad Dermatol Venereol 2018;32:1845-51.

14. Donders GGG, Ruban K, Bellen G, Petricevic L. Mycoplasma/ Ureaplasma infection in pregnancy: to screen or not to screen. J Perinat Med 2017:45:505-15.

15. Taylor-Robinson D, Lamont RF. Mycoplasmas in pregnancy. BJOG 2011;118:164-74.

16. Ollikainen J, Heiskanen-Kosma T, Korppi M, Katila ML, Heinonen K. Clinical relevance of Ureaplasma urealyticum colonization in preterm infants. Acta Paediatr 1998;87:1075-8.

17. Perni SC, Vardhana S, Korneeva I, Tuttle SL, Paraskevas LR, Chasen ST, et al. Mycoplasma hominis and Ureaplasma urealyticum in midtrimester amniotic fluid: association with amniotic fluid cytokine levels and pregnancy outcome. Am J Obstet Gynecol 2004;191:1382-6.

18. Kundsin RB, Leviton A, Allred EN, Poulin SA. Ureaplasma urealyticum infection of the placenta in pregnancies that ended prematurely. Obstet Gynecol 1996;87:122-7.

19. Cassell GH, Waites KB, Watson HL, Crouse DT, Harasawa R. Ureaplasma urealyticum intrauterine infection: role in prematurity and disease in newborns. Clin Microbiol Rev 1993;6:69-87.

20. Witt A, Berger A, Gruber CJ, Petricevic L, Apfalter P, Worda C, et al. Increased intrauterine frequency of Ureaplasma urealyticum in women with preterm labor and preterm premature rupture of the membranes and subsequent cesarean delivery. Am J Obstet Gynecol 2005;193:1663-9.

21. Abele-Horn M, Wolff C, Dressel P, Pfaff F, Zimmermann A. Association of Ureaplasma urealyticum biovars with clinical outcome for neonates, obstetric patients, and gynecological patients with pelvic inflammatory disease. J Clin Microbiol 1997;35:1199202.

22. Kataoka S, Yamada T, Chou K, Nishida R, Morikawa M, Minami M, et al. Association between preterm birth and vaginal colonization by mycoplasmas in early pregnancy. J Clin Microbiol 2006;44:51-5.

23. Varol F, Er N, Sut N, Sayin CN. A Local Study on Antenatal Features of Preterm Births at 26-32 Versus 33-36 Weeks of Pregnancy. Gynecol Obstet Reprod Med 2018;24:1-6.

24. Suzuki Y, Horie K, Yada Y, Kono Y, Hirashima C, Usui R, et al. Vaginal Ureaplasma species increase chorioamnionitis in very preterm infants with preterm premature rupture of the membranes at $<28$ weeks of gestation. Eur JClin Microbiol Infect Dis 2018:37:2371-80.

25. Rumyantseva T, Khayrullina G, Guschin A, Donders G. Prevalence of Ureaplasma spp. and Mycoplasma hominis in healthy women and patients with flora alterations. Diagn Microbiol Infect Dis 2019;93:227-31.

26. Centers for Disease Control and Prevention. Sexually Transmitted Disease Surveillance 2016. Atlanta, GA: US Department of Health and Human Services; 2017.

27. O'Connell CM, Ferone ME. Chlamydia trachomatis Genital Infections. Microb Cell 2016;3:390-403.

28. Redmond SM, Alexander-Kisslig K, Woodhall SC, van den Broek IV, van Bergen J, Ward H, et al. Genital chlamydia prevalence in 
Europe and non-Europeanhigh-incomee countries: systematic review and meta-analysis. PLoS One 2015;23;10:e0115753.

29. Götz HM, van Bergen JE, Veldhuijzen IK, Broer J, Hoebe CJ, Steyerberg EW. Coenen AJ, de Groot F, Verhooren MJ, van Schaik DT, Richardus JH. A prediction rule for selective screening of Chlamydia trachomatis infection. Sex Transm Infect 2005;81:2430.

30. Huai P, Li F, Li Z, Sun L, Fu X, Pan Q, et al. Prevalence, risk factors, and medical costs of Chlamydia trachomatis infections in Shandong Province, China: a population-based, cross-sectional study. BMC Infect Dis 2018;18:534.

31. Kularatne RS, Niit R, Rowley J, Kufa-Chakezha T, Peters RPH, Taylor $\mathrm{MM}$, et al. Adult gonorrhea, chlamydia and syphilis prevalence, incidence, treatment and syndromic case reporting in South Africa: Estimates using the Spectrum-STI model, 1990-2017. PLoS One 2018;13:e0205863.

32. Gaydos C, Maldeis NE, Hardick A, Hardick J, Quinn TC. Mycoplasma genitalium as a contributor to the multiple etiologies of cervicitis in women attending sexually transmitted disease clinics. Sex Transm Dis 2009;36:598-606.

33. Cazanave C, Manhart LE, Bébéar C. Mycoplasma genitalium, an emerging sexually transmitted pathogen. Med Mal Infect 2012;42:381-92.
34. Allen M. Identifying acute cervicitis in an era of less-frequent routine gynecologic examinations. JAAPA 2018;31:50-53.

35. Meites E, Gaydos CA, Hobbs MM, Kissinger P, Nyirjesy P, Schwebke JR, et al. A Review of Evidence-Based Care of Symptomatic Trichomoniasis and Asymptomatic Trichomonas vaginalis Infections. Clin Infect Dis 2015;S837-48.

36. Marrazzo JM. Mucopurulent cervicitis: No longer ignored, but still misunderstood. Infect Dis Clin North Am 2005;19:333-49.

37. Paavonen J, Critchlow CW, DeRouen T, Stevens CE, Kiviat N, Brunham RC, et al. Etiology ofcervicall inflammation. Am J Obstet Gynecol 1986;154:556-64.

38. Brunham RC, Paavonen J, Stevens CE, Kiviat N, Kuo CC, Critchlow $\mathrm{CW}$, et al.Mucopurulent cervicitis-the ignored counterpart in women of urethritis in men. N Engl J Med 1984;311:1-6.

39. Choe HS, Lee DS, Lee SJ, Hong SH, Park DC, Lee MK, et al. Performance of Anyplex ${ }^{\mathrm{TM}}$ II multiplex real-time PCR for the diagnosis of seven sexually transmitted infections: comparison with currently available methods. Int J Infect Dis 2013;17:e1134-40.

40. Whiley DM, Tapsall JW, Sloots TP. Nucleic acid amplification testing for Neisseria gonorrhoeae: an ongoing challenge. J Mol Diagn 2006;8:3-15. 